\title{
PENERAPAN RESTORATIVE JUSTICE TERHADAP PENDAMPINGAN ANAK ASLI PAPUA DALAM SISTEM PERADILAN PIDANA ANAK
}

\author{
Marlyn Jane Alputila \\ Fakultas Hukum Universitas Musamus \\ Jln. Kamizaun - Mopah Lama, Merauke Papua, Indonesia \\ Email :marlyn@unmus.ac.id \\ Mulyadi Alrianto Tajuddin \\ Fakultas Hukum Universitas Musamus \\ Jln. Kamizaun - Mopah Lama, Merauke Papua, Indonesia \\ Email :mulyadi@unmus.ac.id
}

\begin{abstract}
Abstrak
Tujuan penelitian ini bertujuan untuk mengetahui menganalisis peran Bapas Merauke dalam melakukan pendampingan anak asli Papua yang melakukan suatu kejahatan di Kabupaten Merauke dan menganalsis kendala yang dihadapi Pembimbing Kemasyarakatan Bapas Merauke dalam melakukan pendampingan klien anak asli papua. Penelitian merupakan penelitian hukum empiris, yang mengambil lokasi penelitian di Balai Pemasyarakatan Merauke. Pembimbing Kemasyarakatan Bapas Merauke dalam menjalankan perannya untuk menegakan restorative justice dalam pendampingan anak yang berkonflik dengan hukum khususnya anak asli papua dari proses penyidikan hingga pemeriksaan dalam persidangan sudah berjalan optimal dengan diselesaikannya 33 kasus secara diversi dari 42 kasus yang ada. Dalam menjalankan tugasnya Pembimbing Kemasyarakatan Bapas Merauke sering mengalami kendala baik secara internal dan eksternal seperti kurangnya sumber daya manusia, cakupan wilayah yang luas, sarana dan prasarana, serta kurangnya sinergitas dengan instansi terkait.
\end{abstract}

\section{Kata Kunci: Restorative Justice; Anak Asli Papua; Sistem Peradilan Anak.}

\begin{abstract}
This research is intended to analyze the role of Merauke Bapas in assisting native Papuan children who have committed a crime in Merauke Regency. As well as see how the obstacles faced by Bapas Merauke Community Guidance in assisting native Papuan child clients. This research uses empirical juridical research type method with case approach that is analyzed qualitatively. The source of legal material in this paper is primary legal material and secondary legal material which are then obtained results. Bapas Merauke Community Guidance in carrying out its role to uphold restorative justice in assisting children in conflict with the law, especially native Papuan children from the investigation process to the examination in the trial has been running optimally with the completion of 33 cases by diversion from 42 existing cases. In carrying out their duties, the Bapas Merauke Community Guidance often experiences internal and external obstacles such as lack of human resources, wide area coverage, facilities and infrastructure, as well as lack of synergy with related institutions.
\end{abstract}

Keywords: Restorative Justice; Papuan Native Children; Juvenile Justice System.

\section{A. PENDAHULUAN}

Anak merupakan harapan setiap keluarga sebagai pemberian dari Tuhan yang keberadaannya sangat penting dalam sebuah keluarga karena merupakan penerus selain itu anak juga merupakan aset dari suatu Bangsa dan negara Anak sangat penting bagi Negara dalam menjaga generasi pemimpin dan orang-orang yang akan meneruskan cita-cita dan amanat Negara. 
Untuk itu selain orang tua, Negara juga punya peran penting dalam menjaga dan menjamin kelangsungan hidup anak. Negara wajib menjamin dari segi pendidikan, segi kehidupan dan segi hukum. Sesuai dengan Undang-Undang No 35 Tahun 2014 Tentang Perlindungan Anak yaituseorang anak yang belum dewasa atau belum mencapai atau berumur 18 (delapan belas) tahun, termasuk anak yang masih didalam kandungan. ${ }^{1}$ Artinya sepanjang ia belum berumur mencapai batas umur 18 tahun maka ia akan dikategorikan sebagai anak.

Restorative justice merupakan jalan keluar dalam masalah hukum penanganan anak yang bermasalah dengan hukum yang sedang dikembangkan penggunaannya dalam penanganan masalah anak khususnya anak asli Papua. Pendampingan kepada anak asli papua yang berhadapandengan hukum sangat diperlukan upaya dalam hal memberikan perlindungan kepada anak dalamstruktur SPP, tidak hanya dengan melakukan pada proses yang seperti dulu lagi seperti hari ini.Aparat penegak hukum harus mampu terus meningkatkan inovasi dan caracara yang handal dalam proses penyelesaian dan melaksanakan tugasnya.

Dari jumlah kasus tersebut dilansir Lembaga Pemasyarakatan Khusus Anak (LPKA) persentasi kasus pencurian sebesar 23,9\%. Kemudian kasus penyalahgunaan obat terlarang sebesar $17,8 \%$ serta pemerkosaan sebanyak $13,2 \% .^{2}$ Dari data tersebut maka dapat dilihatkejahtan bukan hal baru dan angka yang masuk ke KPAI merupakan angka yang cukup tinggi dan cukup memprihatinkan. KPAI melansir data yang berkaitan dengan kejahatan yang dilakukan oleh anak. Pada tahun 2018 ada 1.855 kasus yang terjadi anak yang melakukan atauanak sebagai pelaku dengan kasus utama adalah pencurian, penyalahgunaan obat terlarang sertapemerkosaan.

Dengan dibentuknya Undang - Undang Nomor 11 Tahun 2012 Tentang SPP Anak dan Undang - Undang No. 35 Tahun 2014 Tentang Perlindungan Anak, hal tersebut dengan jelas memperkuat dan menambah nyata keberadaan atau eksistensi Balai Permasyarakatan dalam sistem peradilan di Indonesia. Di dalam BAPAS peran penting itu dipegang oleh petugas Pembimbing Kemasyarakatan atau lebih dikenal dengan (PK).

Dari data yang didapat di BAPAS Merauke yaitu pada tahun 2018 data anak yang berhadapan dengan hukum yaitu anak Orang asli Papua yaitu Anak sebagai Pelaku sebanyak 17 anak, anak sebagai korban sebanyak 15 anak dan anak sebagai saksi sebanyak 20 anak, sedangkan pada tahun 2019 data anak yang berhadapan dengan hukum yaitu anak sebagai Pelaku yaitu 5 anak, anak sebagai korban yaitu 9 anak dan anak sebagai saksi yaitu 8 anak sehingga total anak Orang Asli Papua yang berhadapan dengan Hukum dalam kurun waktu dua tahun terakhir berjumlah 74 anak. Bila diperhatikan jumlah anak orang asli Papua yang berhadapan dengan Hukum sangat banyak dan terus meningkat. Orang asli Papua yaitu sekumpulan masyarakat atau orang-orang yang berasal dari rumpun ras melanessia yang terdiri dari suku - suku asli di Provinsi Papua dan/ atau orang yang diterima dan diakui sebagai orang asli Papua oleh masyarakat adat Papua. Perhatian terhadap masalah kejahatan telah banyak dilakukan baik dalam bentuk sosialisasi, dalam bentuk memberikan bantuan kepada orang yang kurang mampu maupun memberikan bimbingan yang terbaik dari organisasi-organisasi sosial. Namun sampai sekarang masih tetap menjadi hal yang tetap mendapat perhatian penuh dari pemerintah daerah maupun pemerintah pusat.

Kehidupan keluarga yang masih dibawah standar hidup sehingga banyak anak-anak yang terlantar dan tidak memperoleh pendidikan, pola pikir yang masih sangat rendah dengan perkembangan zaman yang makin pesat. Hal inilah yang mempengaruhi seorang anak dapat melakukan suatu tindakan kejahatandiluar dari apa yang dipikirkan orang dewasa termasuk dalam hal melakukan suatu kejahatan dan hal ini pula yang menjadi banyaknya Anak Asli

${ }^{1}$ Undang-Undang Nomor 35 Tahun 2014 Tentang Perlindungan Anak, Pasal (1)

${ }^{2}$ Data Anak Yang Berhadapan Dengan Hukum (On-Line) Tersedia di: http:Detik.com (16 Januari 2019) 
Orang Papua yang melakukan suatukejahatan karena sering terjadi penelataran terhadap anak dan untuk menghilangkan beban kehidupannya anak lebih memilih untuk menghirup lem aibon atau melakukan aktifitas kejahatan secara bersama-sama maupun sendiri.

Adanya anak yang berada di dalam Lapas sebenarnya telah menyalahi hak-hak anak yang seharusnya diperoleh oleh anak-anak yang berhadapan dengan hukum hal ini menunjukkan bahwa belum tercapainya tujuan hukum yang sebenarnya yaitu kemanfaatan dan kepada kasusanak sendiri pidana penjara adala upaya terakhir atau ultimum remedium sehingga dalam permasalahan yang telah dilakukan oleh anak asli orang Papua perlu mendapat perhatian khusushal ini juga menyangkut dengan kehidupan anak tersebut kedepannya dan kelangsungan maysrakat Papua secara umum.

Dengan adanya permasalahan kejahatan yang dilakukan oleh anak orang asli papua maka penulis mengangkat permasalahan yaitu bagaimankah peran Bapas dalam melakukan pendampingan terhadap klien anak asli Papua serta kendala apasaja yang dihadapi oleh Pembimbing Kemasyarakatan (PK) dalam melakukan pendampingan terhadap klien anak asli Papua untuk mewujudkan asas restorative justice dalam sistem peradilan pidana anak.

\section{B. METODE PENELITIAN}

Dalam penelitian terkait adanya kasus yang dilakukan oleh anak asli papua maka penulis menggunakan pendekatan yuridis empiris. Pendekatan yuridis yaitu Undang - Undang No 35 Tahun 2014 Tentang Perlindungan Anak serta Undang Undang No 11 Tahun 2012 tentang Sistm Perdilan Pidna Anak, UU No 12 Tahun 1995 tentang Pemasyarakatan, sedangkan pendekatan empiris yaitu melihat implementasi dan persoalan-persoalan terkait pendampingan terhadap anak asli Papua dalam system peradilan anak.

\section{PEMBAHASAN}

\section{Peran Bapas Dalam Melakukan Pendampingan Terhadap Klien Anak Asli Papua}

Sistem Peradilan Pidana Anak adalah keseluruhan proses penyelesaian perkara anakyang berhadapan dengan hukum mulai tahap penyelidikan sampai tahap pembimbingansetelah menjalani pidana (Pasal 1 Ayat (1) Undang-Undang Nomor 11 Tahun 2012 TentangSistem Peradilan Pidana Anak). Dalam sistem peradilan pidana anak terdapat suatu lembagayang berperan penting dalam setiap proses penyelesaian perkara anak, yaitu BalaiPemasyarakatan. Balai Pemasyarakatan adalah unit pelaksana teknis pemasyarakatan yangmelaksanakan tugas dan fungsi penelitian kemasyarakatan, pembimbingan, pengawasan, danpendampingan (Pasal 1 Ayat (24) Undang-Undang Nomor 11 Tahun 2012 Tentang Sistem Peradilan Pidana Anak).

Setiap anak yang berhadapan dengan hukum berhak untuk mendapatkan perlindunganbaik fisik, mental, spiritual maupun sosial sesuai dengan prinsip-prinsip Konvensi Hak-HakAnak dan Undang-Undang Nomor 23 Tahun 2003 Tentang Perlindungan Anak yangmeliputi:

a. Non Diskriminasi ;

b. Kepentingan yang terbaik untuk anak;

c. Hak untuk hidup, kelangsungan hidup dan perkembangan;

d. Penghargaan terhadap pendapat anak.

Pembimbing Kemasyarakatan merupakan jabatan teknis yang disandang oleh petugas pemasyarakatan di Balai Pemasyarakatan dengan tugas pokok melaksanakan bimbingan dan penelitian terhadap warga binaan pemasyarakatan sesuai Pasal 8 ayat (1) dan ayat (2) UndangUndang Nomor 12 Tahun 1995 Tentang Pemasyarakatan. Lebih diperjelas dalam Pasal 35 
Peraturan Pemerintah Nomor 31 tahun 1999 tentang Pembinaan dan Pembimbingan Warga

Binaan Pemasyarakatan, klien yang dibimbing oleh Bapas terdiri dari ${ }^{3}$ :

1. Terpidana Bersyarat;

2. Narapidana, Anak Pidana, dan Anak Negara yang mendapat pembebasan bersyarat atau cuti menjelang bebas;

3. Anak Negara yang berdasarkan putusan pengadilan pembinaannya diserahkan kepada orang tua asuh atau badan sosial;

4. Anak Negara yang berdasarkan Keputusan Menteri atau pejabat di lingkungan Direktorat Jenderal Pemasyarakatan yang ditunjuk, bimbingannya diserahkan kepada orang tua asuh atau badan sosial;

5. Anak yang berdasarkan penetapan pengadilan, bimbingannya dikembalikan kepada orang tua atau walinya; dan

6. Anak yang berdasarkan putusan pengadilan, dijatuhi pidana pengawasan; dan Anak yang berdasarkan putusan pengadilan, wajib menjalani latihan kerja sebagai pengganti pidana denda.

Tentang tugas Pembimbing Kemasyarakatan diataur antara lain dalam KeputusanMenteri Kehakiman RI Nomor M.01-PK.04.10 Tahun 1998 tentang Tugas, Kewajiban, dan SyaratSyarat bagi Pembimbing Kemasyarakatan, yaitu :

1. Menyusun laporan hasil penelitian kemasyarakatan yang telah dilakukannya yangdikenal dengan nama laporan hasil penelitian kemasyarakatan (litmas);

2. Mengikuti sidang tim pengamat pemasyarakatan guna memberikan data, saran,dan pertimbangan atas hasil penelitian dan pengamatan yang telah dilakukannya;

3. Mengikutisidangpengadilanyangmemeriksaperkaraanaknakalgunamemberikanpenjelasan, saran, dan pertimbangan kepada hakim mengenai segalasesuatu yang berkaitan dengan anak nakal yang sedang diperiksa di pengadilanberdasarkan hasil penelitian kemasyarakatan yang telah dilakukannya;

4. Melakukan pendampingan, pembimbingan, dan pengawasan terhadap anak dalamproses Sistem Peradilan Anak;

5. Melaporkan setiap pelaksanaan tugas kepada kepala balai pemasyarakatan.

Tugas dan fungsi Pembimbing Kemasyarakatan Dalam Pasal 65 Undang-Undang RINomor

11 Tahun 2012 tentang Sistem Peradilan Pidana Anak, yang belum lama disahkan juga disebutkan bahwa Pembimbing kemasyarakatan bertugas:

1. Membuat laporan hasil penelitian kemasyarakatan untuk kepentingan diversi, melakukan pendampingan, pembimbingan, dan pengawasan terhadap anak selama proses diversi dan pelaksanaan kesepakatan, termasuk melaporkannya kepada pengadilan apabila diversi tidak dilaksanakan;

2. Membuat laporan hasil penelitian kemasyarakatan untuk kepentingan diversi, penyidikan, penuntutan, dan persidangan dalam perkara anak, baik di dalam maupun di luar sidang, termasuk di dalam LPAS dan LPKA;

3. Menentukan program perawatan anak di LPAS dan pembinaan anak di LPKA bersama dengan petugas pemasyarakatan lainnya;

4. Melakukan pendampingan, pembimbingan, dan pengawasan dalam proses peradilan anak dan terhadap anak yang berdasarkan putusan pengadilan dijatuhi pidana atau dikenai tindakan; dan

5. Melakukan pendampingan, pembimbingan, danpengawasanterhadapAnakyangmemperoleh asimilasi, pembebasan bersyarat, cuti menjelang bebas, dan cuti bersyarat.

${ }^{3}$ Pasal 35 Peraturan Pemerintah Nomor 31 tahun 1999 tentang Pembinaan dan Pembimbingan Warga Binaan Pemasyarakatan. 
Keadilan restoratif tidak hanya diarahkan pada pelaku sebagai subjek utama proses, sebaliknya untuk merehabilitasi keadilan dan hukum. Teori restorasi ini mengasumsikan bahwa penuntutan pidana tidak memberikan "pembalasan" dan "perbaikan" kepada pelaku kejahatan, tetapi tidak menyangkal bahwa pelaku kejahatan harus mendapatkansanksi. Hanya saja teori ini lebih berfokus pada penyelesaian konflik daripada hukuman penjara. Menurut teori ini, penjara bukanlah cara terbaik untuk menghadapinya kejahatan. Penjara menurut teori ini adalah bentuk peradaban hukum pidana. ${ }^{4}$

Ahli hukum Marian Liebmann mengartikan restorative justice sebagai suatu sistem hukum yang bertujuan untuk mengembalikan kesejahteraan korban, pelaku, dan masyarakat yang rusak oleh kejahatan, dan untuk mencegah pelanggaran atau tindakan kejahatan lebih lanjut. ${ }^{5}$ Akan tetapi ada sedikit berbeda pandangan mengenai definisi keadilan restoratif dari Rocky Marbun dimana beliau menjelaskan bahwa keadilan restoratif sebagai suatu pendekatan keadilan yang memfokuskan kepada kebutuhan daripada para korban, pelaku kejahatan, dan juga melibatkan peran serta masyarakat, dan tidak semata-mata memenuhi ketentuan hukum atau sematamata penjatuhan pidana. ${ }^{6}$ Menurutnya keadilan restoratif tidak selalu harus mengikuti apa yang tertuang dalam suatu peraturan perundang-undangan melainkan lebih menekankan pada peneyelesaian berdasarkan kemanfaatan dan kebaikan semua pihak yang terlibat.

Menurut Heince yang saat penelitian dilakukan menjabat sebagai Kepala Subseksi Bimbingan Klien Anak di Balai Pemasyarakatan Merauke, diperoleh informasi bahwa peran Balai Pemasyarakatan dalam pembimbingan terhadap anak nakal dilakukan oleh petugas pembimbing kemasyarakatandari Balai Pemasyarakatan yang memdampingi klien anak mulai dari penyidikan, penuntutan, persidangan, hingga pelaksanaan putusan hakim. Pembimbing kemasyarakatan mempunyai peranan yang sangat strategis dalam penanganan terhadap anak nakal, hal ini terjadi karena pembimbing kemasyarakatan mempunyai dua (dua) peranan yang melekat dalam mata rantai proses penegakan hukum yaitu tahap penyelidikan dan penyidikan serta tahap pemeriksaan pengadilan. ${ }^{7}$

\section{Tahap Penyelidikan dan Penyidikan}

Di Indonesia proses penanganan terhadap para pelanggar hukum dilakukan dengan sistim peradilan pidana terpadu (Integrated Criminal Justice System). Proses tersebut meliputi tahap tahap yang terintegrasi dan dilaksanakan oleh Aparat Penegak Hukum (APH). Proses diawali dengan Penyelidikan dan penyidikan, yang dilaksanakan oleh Polisi, selaku penyidik, untuk memperoleh bukti yang cukup bahwa telah terjadi tindak pidana. Tahap ini disebut sebagai Tahap Pra Ajudikasi.Balai Pemasyarakatan mulai berperan dalam penyelesaian perkara secara diversi terhadap anak yang berhadapan dengan hukum ketika ada permintaan penelitian kemasyarakatan (Litmas) dari pihak penyidik (polisi) baik Polres atau Polsek sesuai denganwilayah kerja Balai Pemasyarakatan Kelas II Kabupaten Merauke.

\section{Tahap Pemeriksaan Pengadilan}

Pada tahap pemeriksaan pengadilan, peran strategis Bapas adalah memberikanpendampingan terhadap anak dalam sidang pengadilan. membacakan laporan hasil penelitian kemasyarakatan setelah surat dakwaan dibacakan, hadir pada saat pemeriksaan Anak Korban dan / atau Anak Saksi. Melakukan pendampingan terhadap Anak Korban dan / atau Anak Saksi yang dilakukan

${ }^{4}$ Mulyadi Alrianto Tadjuddin, Yuldiana Zesa Aziz. Protection of Papuan Native Children Conflicting with Lawthrough a Restorative Justice Approach. Musamus Law Review, 1 (1), 2018 hlm. 9.

${ }^{5}$ Liebmman, M. Restorative Justice. (2007). How it Works.London:Jessica Kingsley, Publishe, hlm. 25.

${ }^{6}$ Marbun, R. (2012). Membangun Restorative Justice Dan Penal Mediation Dalam Sistem Peradilan Pidana Di Indonesia, hlm. 7.

${ }^{7}$ Hasil wawancara dengan Heince, selaku Kepala Subseksi Bimbingan Klien Anak di Balai Pemasyarakatan Merauke, pada Oktober 2019. 
pemeriksaan langsung jarak jauh dengan alat komunikasi audiovisual. (Pasal 58 ayat (3) UU SPPA) Laporan hasil penelitian kemasyarakatan yang di sampaikan oleh PK Bapas wajib menjadi bahan pertimbangan Hakim dalam menjatuhkan putusan dalam perkara anak. Dan apabila laporan penelitian kemasyarakatan ini tidak di pertimbangkan dalam putusan Hakim, maka putusan batal demi hukum. Pengadilan mempunyai kewajiban memberikan petikan putusan pada hari putusan di ucapkan, selain kepada Anak atau Advokat atau pemberi bantuan hukum lainnya, dan Penuntut Umum, juga memberikan kepada Pembimbing Kemasyarakatan. Sedangkan salinan putusan wajib diberikan paling lama 5 (lima) hari sejak putusan diucapkan kepada Anak atau Advokat atau pemberi bantuan hukum lainnya, Pembimbing Kemasyarakatan, dan Penuntut Umum.

Tabel 1. Jumlah Kasus Yang Dapat Dilakukan Diversi

\begin{tabular}{rrrrrr}
\hline No & $\begin{array}{r}\text { Tahun Kasus Narap- } \\
\text { idana Anak }\end{array}$ & $\begin{array}{r}\text { Jumlah Narapi- } \\
\text { dana Anak }\end{array}$ & $\begin{array}{r}\text { Orang Asli } \\
\text { Papua }\end{array}$ & Pendatang & $\begin{array}{r}\text { Diversi } \\
\text { Anak } \\
\text { Papua }\end{array}$ \\
\hline 1 & 2017 & 16 & 11 & 5 & 7 \\
2 & 2018 & 27 & 16 & 11 & 11 \\
3 & 2019 & 22 & 15 & 7 & 15 \\
\hline
\end{tabular}

Sumber : Balai Pemasyarakatan Klas II Merauke

Dari tabel diatas menunjukan jumlah anak yang berkonflik dengan hukum berasal dari suku Orang Asli Papua (OAP) pada tahun 2017 dari 16 kasus, 11 orang OAP 7 dapat dilakukan Diversi, pada tahun 2018 dari 27 kasus, 16 orang OAP 11 dapat dilakukan Diversi, pada tahun 2019 dari 22 kasus, 15 orang OAP 15 dapat dilakukan Diversi.

Terkait dengan impelementasi diversi dalam Undang-Undang No. 11 Tahun 2012 Tentang Sistem Peradilan Pidana Anak, Polres Merauke hingga saat ini hanya siap jika hasil diversi sebagaimana diatur dalam Pasal 11 UU SPPA berupa perdamaian dan penyerahan kembali ke orang tua/wali. Penyerahan anak yang berkonflik dengan hukum ke orang tua/wali terkhususnya orang asli papua adalah tidak tepat dengan melihat kondisi ekonomi dan lingkungan orang tua/wali. Bentuk diversi yang diterapkan dengan anak yang berkonflik dengan hukum khusus suku dari asal lain (Bugis, Jawa, Batak, Ambon dll.) hanya wajib lapor bagi pelaku setiap hari senin dan kamis dikarenakan ada jaminan yang diberikan dari pihak keluarga maupun sekolah. Sebaiknya pihak Penyidik melibatkan Tokoh Adat dan Tokoh Agama dalam hal diversi, dan pengawasan di sekolah kerja sama dengan Dinas Pendidikan dan Pengajaran Kabupaten Merauke. Perlu adanya bentuk diversi lain seperti kerja sosial dan pendidikan/ pelatihan sebagaimana diatur dalam Pasal 11 Undang-Undang No 11 Tahun 2012 Tentang Sistem Peradilan Pidana Anak yang melibatkan dinas sosialPemerintah Kabupaten Merauke dan Pusat Pelayanan Terpadu Pemberdayaan Perempuan Dan Anak (P2TP2A).

Tabel 2. Latar Belakang Pendidikan Pelaku Anak Asli Papua

\begin{tabular}{rrrrrr}
\hline \multirow{2}{*}{ Tahun } & \multirow{2}{*}{ Pelaku } & & & & Pendidikan \\
\cline { 3 - 6 } & & SD & SMP & SMA/SMK & Putus Sekolah \\
\hline 2017 & 11 & 1 & 7 & - & 2 \\
2018 & 16 & - & 6 & 10 & - \\
2019 & 11 & $\mathbf{3}$ & $\mathbf{1 8}$ & $\mathbf{1 5}$ & - \\
\hline Total & $\mathbf{3 8}$ & &
\end{tabular}

Sumber : Balai Pemasyarakatan Klas II Merauke

Bapas Merauke sebagian besarklien anak asli Papuayang sebagian besarnya masihbersekolah dengan jumlah 38 (tiga puluh delapan) jiwa. 3 (tiga) orang anak masih bersekolah di SD, 18 (delapan belas) bersekolah di SMP, 15 (lima belas) masih sekolah di SMA, dan 2 (dua) 
orang anak putus sekolah. Latar belakang pendidikan tersebut bisa dijadikan sebagai indicator penyebab mereka melakukan kejahatan dan menjadikan pendekatan khusus oleh Pembimbing Kemasyarakatan yang memeliki latar belakang pendidikan yang rendah.

Berdasarkan tabel tersebut ditunjukan bahwa tingkat pendidikan anak orang asli papua yang berkoflik dengan hukum yang paling tinggi adalah SMP, dengan hal tersebut perlu ektra atau lebih agar anak orang asli papua yang berkonflik dengan hukum benar-benar paham, mengerti tentang kesadaran hukum yang diberikan oleh Pembimbing Kemasyarakatan selama melakukan pendampingan.

\section{Kendala Yang Dihadapi Oleh Pembimbing Kemasyarakatan Dalam Melakukan Pendampingan Terhadap Klien Anak Asli Papua.}

Hambatan-hambatan yang ditemui oleh Bapas Merauke dalam pembimbingan anaknakal yang dilakukan oleh Pembimbing Kemasyarakatan Klien Anak berasal dari faktor intern dan faktor ekstern. Faktor intern yaitu faktor yang berasal dari Bapas Merauke, sedangkan faktor ekstern yaitu faktor yang berasal dari Bapas Merauke. Adapun hambatan hambatan yang ditemui Bapas Merauke dalam pembimbingan anak nakal antara lain:

\section{a. Kurangnya Tenaga Ahli dan Sumber Daya Manusia}

Semakin banyak tenaga ahli dalam hal penegak hukum (law enforcement) maka akansemakin baik terlebih bila daerah cakupan wilayahnya luas sekali. Hal tersebut yang menjadi kendala pertama bagi PK BAPAS Merauke dalam menjalankan tugas dan perannya.

Tabel 3. Anggota Pembimbing Kemasyarakatan Bapas Merauke

\begin{tabular}{rrrrr}
\hline No & Nama & NIP & Status & Masa Bakti \\
\hline 1 & Arif Widyarso, SH & 198609082017121001 & Tersedia & 2 Tahun \\
2 & Riza Anugrah Septiawan, S. Sos & 198709212018011002 & Pelatihan & 2 Tahun \\
3 & AF. Danny Firmansyah S.Psi & 199001122017121001 & Pelatihan & 2 Tahun \\
4 & Setia Maryam Febby K. H, S.Sos & 1985020442006042001 & Tersedia & 12 Tahun \\
5 & Dandy Satyagraha Burhan W. & 199306072017121001 & Tersedia & 2 Tahun \\
& S.Psi & & & \\
6 & Heince, SE. SH & 197706142006041001 & Tersedia & 12 Tahun \\
\hline
\end{tabular}

Sumber : Balai Pemasyarakatan Klas II Merauke

Berdasarkan tabel di atas, Bapas Merauke mempunyai 6 (empat) orang PembimbingKemasyarakatan Klien Anak yang terdiri dari:, 2 (dua) orang lulusan Psikologi, dan 4 (empat) orang lulusan Strata I. Terkait mengenai jabatan dalam membimbing klien dewasa maupun klien anak, tidak ada persyaratan khusus yang harus dimiliki oleh Pembimbing Kemasyarakatan (PK) dalam membimbing klien dewasa maupun klien anak, sedangkan yang membedakan hanya mengenai klien yang ditangani. Untuk klien anak yang dibimbing oleh Pembimbing Kemasyarakatan Klien Anak adalah anak yang berusia 8 (delapan) sampai dengan 21 (dua puluh satu) tahun, sedangkan untuk klien dewasa yang dibimbing oleh Pembimbing Kemasyarakatan Klien Dewasa adalah klien yang berusia lebih dari 21 (dua puluh satu tahun).

Dari tabel di atas dapat dikemukakan bahwa Pembimbing Kemasyarakatan Klien Anak yang tingkat pendidikannya berasal dari bidang/jurusan psikologi hanya ada dua orang yaitu AF Danny Firmansyah S.Psi dan Dandy Satyagraha Burhan W S.Psi sehingga sumber daya manusia yang ada dari Pembimbing Kemasyarakatan Klien Anak Bapas Merauke masih perlu ditingkatkan baik dari segi kualitas maupun dari segi kuantitas. 
Sehubungan dengan tingkat pendidikan personil Pembimbing Kemasyarakatan Klien Anak Bapas Merauke dimana hanya ada dua orang Pembimbing Kemasyarakatan Klien Anak dari lulusan psikologi, maka Pembimbing Kemasyarakatan Klien Anak mengikuti diklat-diklat yang terkait dengan pembimbingan anak nakal agar lebih mendalami permasalahan anak nakal dan pembimbingan yang tepat bagi anak nakal tersebut. Dengan mengikuti diklat-diklat tentang pembimbingan anak nakal, tentunya dapat menambah wawasan dan pengetahuan Pembimbing Kemasyarakatan Klien Anak di Bapas Merauke.

Untuk itulah diperlukan sekali pemahaman kepada petugas Pembimbing Kemasyarakat Bapas dengan pelatihan Bimbingan dan Teknis yang harus diberikan kepada petugas Pembimbing Kemasyarakat Bapas. Pelatihan yang akan memberikan dampak yang besar bagi kinerja petugas Pembimbing Kemasyarakat Bapas Merauke sendiri. Dengan adanya pelatihan maka hambatan-hambatan yang dialami akan berkurang dan akan meningkatnya kinerja Pembimbing Kemasyarakat Bapas dengan sendirinya.

\section{b. Cakupan Wilayah yang Luas}

Wilayah kerja Bapas Merauke meliputi Kabupaten Merauke, Boven Digoel, Mappi,dan Asmat. Terlalu luasnya jangkauan wilayah kerja Bapas Merauke menjadi salah satu hambatan bagi Pembimbing Kemasyarakatan Klien Anak karena pembimbingan untuk wilayah yang jauh dari kantor Bapas tentunya memakan waktu yang lebih lama. Sebagai contoh pembimbingan terhadap klien anak yang berinisial DN yang tempat tinggalnya berada di daerah Asmat Agats. Tempat tinggal DN selain jauh dari kantor Bapas Merauke,juga mengenai area geografis yang dilalui menuju ke rumah DN agak sedikit sulit dilalui karena di daerah pinggiran kali. Apabila kunjungan ke rumah klien anak untuk wilayah yang jauh dan klien anak tersebut tergolong dengan keadaan ekonomi yang kurang mampu, dan tidak memiliki sarana komunikasi seperti telp maupun hand phone maka Pembimbing Kemasyarakatan Klien Anak berusaha untuk menyesuaikan dengan keadaan dan melaksanakan pimbimbingan klien anak sampai dengan selesai. Misalnya Pembimbing Kemasyarakatan Klien Anak mensiasati dengan cara memperkirakan waktu kunjungan ke rumah klien anak di saat klien anak tersebut berada di rumah.

\section{c. Kurang Sinergitas Dengan Instansi Terkait}

InimerupakansalahsatufaktorpenghambatyangcukupseriusbagiPembimbingKemasyarakat Bapas Merauke dalam menjalankan tugasnya sebagai pendamping dan pembimbing anak ketika menghadapi permasalahan pidana. Ketidakselarasan dengan para pihak penegak hukum yang lainnya (misalnya kepolisian dan kejaksaan) adalah hal yang cukup sering terjadi dan dialami oleh petugas Bapas Merauke. Hal seperti ini sering disebut dengan ego sektoral.

Terkadang pihak kepolisian dalam hal ini penyidik merasa mempunyai wewenang yang lebih berkuasa dari petugas Pembimbing Kemasyarakat Bapas Merauke. Dengan berdasarkan pemahaman pihak kepolisian tersebut, maka sering sekali dijumpai bahwa penyidik kepolisian memeriksa anak yang berkonflik dengan hukum tanpa adanyaketerlibatan pihak petugas Pembimbing Kemasyarakat Bapas Merauke.

Bahkan seringkali didapati penyidik kepolisian hanya meminta tanda tangan berita acara dari pihak petugas Pembimbing Kemasyarakat Bapas Merauke tanpa sama sekali berinteraksi terlebih dahulu dengan petugas Pembimbing Kemasyarakat Bapas Merauke.

Artinya ada keegoisan sektoral yang dibuat oleh pihak penyidik kepolisian Merauke. Hal tersebut didasari karena minimnya pengetahuan dan pemahaman pihak penyidik kepolisian terkait Undang-Undang Nomor 11 Tahun 2012 Tentang Sistem Peradilan Pidana Anak Dalam pasal disebutkan bahwa ketika ada tindak pidana yang dilakukan dengan anak maka ketika 
proses pemeriksaan dilangsungkan harus melibatkan orang tua anak baik dari pihak korban dan pelaku, tua-tua adat dan petugas Pembimbing Kemasyarakat Bapas. ${ }^{8}$

Kemudian, masih menurut penyampaian beliau, tidak hanya dari pihak kepolisian, pihakpihak lain terkadang beberapa kali sangat sulit diajak bekerja sama seolah-olah tidak ingin terlibat dalam proses tersebut. Misalnya pihak lain seperti pengacara dan dinas sosial yang terkait. Pengacara terkadang menggangap petugas Pembimbing Kemasyarakat Bapas Merauke menganggu proses dan terkesan terlalu melindungi anak yang sedang berkonflik dengan hukum tersebut.

\section{d. Sarana dan Prasarana}

Faktor selanjutnya yang dapat menjadi kendala dalam kinerja petugas Pembimbing Kemasyarakat Bapas Merauke adalah terkait sarana dan prasarana yang masih belum memadai. Sarana dan prasarana menjadi faktor yang cukup penting untuk mendukungkinerja petugas Pembimbing Kemasyarakat Bapas Merauke. Apabila sarana dan prasarana kurang memadai maka akan menjadi salah satu faktor penghambat kinerja Pembimbing Kemasyarakat Bapas Merauke. Misalnya saja bangunan Bapas Merauke yang dinilai belum cukup luas. Kemudian dari segi kendaraan operasional yang masih kurang di Bapas Merauke. Padahal kendaraan operasional mempunyai peran yang cukup vital dalam hal mobilitas bagi petugas Pembimbing Kemasyarakat Bapas Merauke. Terlebih dengan luasnya daerah cakupan dan sering terjadi banyaknya kasus maka ketika tidak ada jumlah kendaraan yang memadai untuk berpergian dari tempat satu ke tempat yang lain maka akan sangat sulit sekali bagi Pembimbing Kemasyarakat Bapas Merauke untuk menjalankan tugasnya dengan maksimal.

Tidak hanya sarana dan prasarana di luar lapangan, tetapi di dalam juga masih ada sarana dan prasaran yang dinilai belum cukup baik untuk meningkatkan kinerja petugas Pembimbing Kemasyarakat Bapas Merauke. Berdasarkan penuturan Saudara Dandy Satyagraha jumlah unit komputer yang minim masih sering menjadi kendala bagiPembimbing Kemasyarakat Bapas Merauke terutama ketika ingin membuat laporan penelitian yang di mana notabenya menjadi acuan hakim untuk menjatuhkan putusan. Apabila laporan litmas yang dibuat tidak baik maka akan menjadi bumerang tersendiri bagi petugas Pembimbing Kemasyarakat Bapas Merauke. Untuk itu diperlukan sekali tambahan beberapa unit komputer yang memadai.

Diharapkan pemerintah dalam hal ini (Kemenkumham) untuk memberikan bantuan yang cukup agar kantor Bapas Merauke dapat menciptakan bangunan yang lebih luas untuk mengakomodir para anak-anak yang dalam proses pembimbingan, serta menambah jumlah unit kendaraan operasional agar lebih banyak lagi dengan tujuan agar lebih mudahnya tercapai lokasi-lokasi yang cukup jauh dari jangkauan petugas Pembimbing Kemasyarakat Bapas Merauke. Terutama apabila jumlah petugas Pembimbing Kemasyarakat Bapas menjadi bertambah dari jumlah yang sudah ada. Kemudian dari segi administrasi pembuatan litmas, kiranya dapat diberikan dan ditambahkan jumlah unit komputer yang lebih baik lagi untuk memudahkan Pembimbing Kemasyarakat Bapas Merauke melakukan kinerjanya agartercapainya perwujudan dari marwah Undang-Undang Nomor 11 Tahun 2012 Tentang Sistem Peradilan Pidana Anak. ${ }^{9}$

\section{KESIMPULAN}

Balai Pemasyarakatan memiliki peran dalam penyelesaian perkarapidana anak melalui diversi dan Balai Pemasyarakatan berperan sangat aktif dalam penyelesaian kasus tersebut terbukti dengan dari 42 (empat puluh dua) kasus anak asli orang papua yang berhadapan

\footnotetext{
${ }^{8}$ Ibid.

${ }^{9}$ Hasil wawancara dengan Dandy Satyagraha, selaku petugas PK BAPAS Merauke, pada Oktober 2019
} 
dengan hukum yang telah di ditangani, 33 kasus oleh Balai Pemasyarakatan. Hambatan yang ditemui dalam pembimbingan anak nakal terdiri dari faktor intern terdiri dari kurangnya tenaga ahli dan sumber daya manusia, dan memiliki cakupan wilayah yang luas (faktorberasal dari Bapas Merauke dan faktor ekstern yang terdiri dari kurangnya sinergitas dari instansi terkait dan sarana dan prasarana (faktor yang beraskeal dari luar BapasMerauke). Diharapkan Kantor Bapas Merauke yang di bawah naungan Kemenkumham dapat menambah jumlah formasi anggota Pembimbing Kemasyarakatan Merauke serta membuka penerimaan terutama bagi mereka yang sudah memiliki dan memenuhi persyaratan sebagai petugas Pembimbing Kemasyarakatan Bapas Merauke. Diharapkan kepada pihak kepolisian, apabila ada laporan terkait tindak pidana yang dilakukan oleh anak asli papua, maka harus memanggil pihak keluarga dari si anak tersebut atau tokoh agama dan adat untuk dapat dilakukan penyelesaian permasalahan tersebut dengan melalui diversi.

\section{Daftar Pustaka}

\section{Buku}

Liebmman. (2007).M. Restorative Justice; How it Works. Publishe. London:Jessica Kingsley.

Marbun, R. (2012)Membangun Restorative Justice Dan Penal Mediation Dalam Sistem Peradilan Pidana Di Indonesia.

\section{Jurnal}

Mulyadi Alrianto Tadjuddin, Yuldiana Zesa Aziz.(2018). Protection of Papuan Native Children Conflicting with Lawthrough a Restorative Justice Approach. Musamus Law Review, $1(1)$.

\section{Internet}

Data Anak Yang Berhadapan Dengan Hukum (On-Line) Tersedia di: http:Detik.com (16 Januari 2019)

\section{Peraturan Perundang - Undangan}

Republik Indonesia. Undang-Undang Tentang Perubahan Atas Undang-Undang Nomor 23 Tahun 2002 tentang Perlindungan Anak. UU Nomor 35 Tahun 2014. LNRI Tahun 2014 Nomor 297. TLNRI Nomor 5606

Peraturan Pemerintah Nomor 31 tahun 1999 tentang Pembinaan dan Pembimbingan Warga Binaan Pemasyarakatan. 